\title{
Oxytocin receptor binding activity in cultured ovine endometrium
}

\author{
E. L. Sheldrick, H. C. Flick-Smith and G. J. Dos Santos Cruz \\ AFRC, Institute of Animal Physiology and Genetics Research, Babraham, Cambridge CB2 4AT, UK
}

\begin{abstract}
Oxytocin receptor binding activity in explants of caruncular and intercaruncular endometrium collected from luteal phase ewes increased during culture. An initial rise in binding activity occurred during the first $24 \mathrm{~h}$ of culture in both tissues; binding activity in intercaruncular endometrium continued to increase until day 6 , remained unchanged on day 8 and had decreased by day 10 of culture. The maximum concentration of receptors in caruncular endometrium was significantly lower than that in intercaruncular endometrium $(P<0.001)$ and did not change significantly between days 4 and 10 of culture. Apparent dissociation constants and maximal binding of oxytocin receptor in cultured caruncular and intercaruncular endometrium were 3.09 and $2.72 \mathrm{nmoll}^{-1}$ and 249 and $459 \mathrm{fmol}\left[{ }^{3} \mathrm{H}\right]$ oxytocin bound $\mathrm{mg}^{-1}$ protein, respectively. Concentrations of oxytocin receptor remained constant in myometrium during $96 \mathrm{~h}$ of culture. The rise in endometrial oxytocin receptor concentration did not result from exposure to fetal calf serum, phenol red or insulin in the culture medium. Substituting fetal calf serum with sheep serum or BSA did not block the rise in receptor binding activity. Actinomycin D and cycloheximide inhibited the rise in receptor concentration in both tissues. Co-culture of lung or kidney with endometrium had no effect on binding activity, whereas co-culture with luteal tissue effectively reduced the rise in oxytocin receptor concentration. To establish whether synthesis of functional oxytocin receptors occurred during culture, the effect of oxytocin on prostaglandin $\mathrm{F}_{2 \alpha}\left(\mathrm{PGF}_{2 \alpha}\right)$ production was assessed in fresh tissue and after $48 \mathrm{~h}$ in culture. No $\mathrm{PGF}_{2 \alpha}$ was secreted in response to oxytocin on the day of tissue collection, but after $48 \mathrm{~h}$ oxytocin-induced $\mathrm{PGF}_{2 \alpha}$ production occurred in intercaruncular endometrium and to a lesser extent in caruncular endometrium. Indomethacin reduced basal and oxytocin-induced $\mathrm{PGF}_{2 \alpha}$ production in both cultured tissues. These data show that de novo synthesis of functional oxytocin receptors occurs during culture and can be inhibited by a secretory product of the corpus luteum.
\end{abstract}

\section{Introduction}

Uterine oxytocin receptors play an important role in regulating secretion of prostaglandin $\mathrm{F}_{2 \alpha}\left(\mathrm{PGF}_{2 \alpha}\right)$ during the ovine oestrous cycle (see Flint et al., 1990; Silvia et al., 1991 for reviews). Oxytocin interacts with the uterine oxytocin receptor to stimulate episodes of $\mathrm{PGF}_{2 \alpha}$ secretion during luteolysis, and the ability of oxytocin to increase PGF $_{2 a}$ secretion has been used to indicate the presence of a functional uterine oxytocin receptor in experiments in vivo (Vallet et al., 1990) and in vitro (Roberts et al., 1976). Concentrations of uterine oxytocin receptor rise during luteolysis, are maximal at oestrus and then decrease rapidly to reach low values by day 4 after oestrus (Roberts $e$ t al., 1976; Sheldrick and Flint, 1985), with a low level of receptor being maintained throughout the luteal phase (days 5-13) of the oestrous cycle (Sheldrick and Flint, 1985) when luteal secretion of progesterone and oxytocin is maximal (Flint and Sheldrick, 1983). Both of these hormones have been implicated in the control of oxytocin receptor synthesis in vivo. Oxytocin given by continuous intravenous infusion to ewes from day 12 or 13 after oestrus prevents episodic secretion of $\mathrm{PGF}_{2 \alpha}$ and the increase in

Received 9 September 1992. uterine oxytocin receptor concentration associated with luteolysis and consequently delays luteal regression (Flint and Sheldrick, 1985; Sheldrick and Flint, 1990). However, this apparent downregulation of the oxytocin receptor by oxytocin can be reversed by administration of cloprostenol, a luteolytic $\mathrm{PGF}_{2 \alpha}$ analogue. Cloprostenol-induced luteolysis in ewes infused with oxytocin is associated with decreasing concentrations of progesterone in plasma and raised concentrations of uterine oxytocin receptor, similar to those seen in untreated ewes during luteolysis (Flint and Sheldrick, 1985). When plasma progesterone concentrations are maintained, by administration of exogenous progesterone in oxytocin-treated ewes corpora lutea regress in response to cloprostenol but oxytocin receptor concentrations remain low (Sheldrick, 1992). Thus progesterone appears to be a requirement for low uterine oxytocin receptor concentrations and reduced secretion of $\mathrm{PGF}_{2 \alpha}$.

In experiments designed to investigate control of oxytocin receptor synthesis in vitro, receptor synthesis in explants of rat uterus have been shown to be influenced by progesterone and oestradiol (Soloff et al., 1983). However, as oxytocin has not been detected in the rat ovary (Clements and Funder, 1986), the mechanism by which oxytocin receptor production is controlled in the rat may be different from that in the ewe where 
oxytocin produced by the ovary appears to play an important role in controlling oxytocin receptor synthesis and thereby regulating the duration of the oestrous cycle. Preliminary experiments have shown that a spontaneous increase in oxytocin receptor binding activity occurs when ovine endometrium, collected during the luteal phase of the oestrous cycle, is maintained in organ culture (Sheldrick, 1990; Sheldrick, 1991). The experiments described here were designed to investigate whether de novo synthesis of functional oxytocin receptors occurs during culture and, if it does, whether it results from stimulation by a hormonal factor in the culture medium or is independent of hormonal stimulation possibly resulting from disinhibition: that is, whether removal of the reproductive tract from the ewe releases the uterus from the influence of a circulating inhibitor of receptor synthesis. Identification of such a substance would further our knowledge of the factors involved in regulating the length of the ovine oestrous cycle.

\section{Materials and Methods}

\section{Animals}

Reproductive tracts from 17 parous Clun Forest ewes were collected aseptically on eight separate days of the luteal phase of the oestrous cycle (day $5, n=2$; day $6, n=3$; day $7, n=2$; day $9, n=3$; day $10, n=3$; day $11, n=2$; day $12, n=1$; day $13, n=1$; day of oestrus = day 0 ), following administration of pentobarbitone sodium (Lethobarb: Duphar Veterinary Ltd, Southampton). Tissue from each ewe was cultured as a separate experiment. In co-culture experiments lung, kidney and corpora lutea were collected aseptically for co-culture with endometrium obtained from the same ewe. None of the ewes used in these experiments was given exogenous hormone treatment.

\section{Tissue culture}

The medium used in these experiments was Trowell T8 (Trowell, 1959) prepared in this laboratory with $2 \mathrm{mmol} \mathrm{L}$ glutamine $\mathrm{l}^{-1}, 100 \mathrm{iu}$ penicillin $\mathrm{ml}^{-1}, 100 \mu \mathrm{g}$ streptomycin sulfate $\mathrm{ml}^{-1}$ and fetal calf serum $(5 \% \mathrm{v} / \mathrm{v}$; all purchased from Gibco, Paisley). This medium is referred to as 'control medium' in experiments where alterations to this formula are made. Trowell T8 contains $10 \mathrm{mg}$ phenol red $\mathrm{I}^{-1}$ and $10 \mu \mathrm{mol}$ bovine insulin $1^{-1}$ (both Sigma Chemical Company, Poole, Dorset).

Aseptic procedures were used to dissect myometrium and endometrium from the uterus and caruncular and intercaruncular endometrium were separated into Petri dishes containing culture medium. The tissues were chopped into $1 \mathrm{~mm}$ cubes using a Mcllwain tissue chopper (Mickle Laboratory Engineering Ltd, Guildford, Surrey). The explants were washed with medium before being placed onto sterile lens cleaning tissue (105: Whatman International Ltd, Maidstone) supported by expanded stainless steel grids $(20 \mathrm{~mm} \times 15 \mathrm{~mm} \times 3 \mathrm{~mm}$ high). Three grids, representing $150-250 \mathrm{mg}$ tissue, were placed into each Petri dish $(6 \mathrm{~cm}$ diameter 1007: Falcon, Becton Dickinson, Plymouth). The volume of medium (approximately $9 \mathrm{ml}$ per dish) was sufficient to bathe the lens tissue, but not submerge the explants (Trowell, 1959). Explants were cultured for up to 10 days at $37^{\circ} \mathrm{C}$ in a humidified atmosphere of $95 \%$ air:5\% $\mathrm{CO}_{2}$. Medium was changed daily and viability of explants assessed histologically after fixation in Bouin's solution and staining with haematoxylin-eosin. Histological examination of cultured explants confirmed that tissue viability was maintained throughout the experiments in all tissues used. All experiments were performed using three replicate dishes for each treatment for each tissue.

At the end of culture, explants were removed from the lens tissue and washed in 100 volumes of ice-cold $154 \mathrm{mmol}$ $\mathrm{NaCll}^{-1}$ containing $1 \mathrm{mmol}$ EDTA ${ }^{-1}$. The explants were homogenized in ice-cold Tris- $\mathrm{HCl}\left(25 \mathrm{mmol} \mathrm{l}^{-1} ; \mathrm{pH} 7.6\right)$ containing sucrose $\left(0.25 \mathrm{moll}^{-1}\right)$ and EDTA $\left(1 \mathrm{mmol} \mathrm{l}^{-1}\right)$, using an Ultra Turrax homogenizer $(3 \times 10 \mathrm{~s})$. The tissue was then further homogenized using a Teflon-glass Dounce homogenizer. The homogenates were centrifuged at $2000 \mathrm{~g}$ for $10 \mathrm{~min}$ and the resulting supernatants centrifuged at $100000 \mathrm{~g}$ for $1 \mathrm{~h}$. Pellets were washed with Tris- $\mathrm{HCl}\left(25 \mathrm{mmol} \mathrm{l}^{-1}, \mathrm{pH} 7.6\right)$ and then resuspended, by homogenization (Teflon-glass Dounce homogenizer), in this buffer and stored at $-80^{\circ} \mathrm{C}$ before assay of oxytocin binding and protein concentration.

\section{Oxytocin radioreceptor assay}

Oxytocin receptor binding activity was measured by the method of Sheldrick and Flint (1985). Briefly, receptor fractions $\left(50 \mu \mathrm{g}\right.$ protein) were incubated at $25^{\circ} \mathrm{C}$ for $15 \mathrm{~min}$ in $0.1 \mathrm{ml}$ Tris-HCl $\left(25 \mathrm{mmoll}^{-1}\right.$; pH 7.6) containing $0.1 \%(\mathrm{w} / \mathrm{v})$ BSA, $\mathrm{MnCl}_{2}\left(1 \mathrm{mmol}{ }^{-1}\right)$ and $\left[3,5-{ }^{3} \mathrm{H}-\mathrm{Tyr}\right]$ oxytocin $\left(5 \mathrm{nmoll}^{-1}\right.$, $1224 \mathrm{GBq}$ mmol; NEN Research Products, Stevenage, Herts). Nonspecific binding was measured in the presence of $10 \mu \mathrm{mol}$ unlabelled oxytocin $\mathrm{l}^{-1}$ (Bachem UK Ltd, Saffron Walden, Essex). After incubation, tubes were transferred to an ice-bath and $2 \mathrm{ml}$ ice-cold Tris- $\mathrm{HCl}\left(25 \mathrm{mmol} \mathrm{l}^{-1}\right.$; $\left.\mathrm{pH} 7.6\right)$ containing BSA $(0.1 \%$ $\mathrm{w} / \mathrm{v}$ ) was added to each tube. Separation of free oxytocin from receptor-bound oxytocin was by filtration under vacuum using glass microfibre filters $(\mathrm{GF} / \mathrm{F}$; Whatman International Ltd, Maidstone) in a sampling manifold (No. 1225; Millipore UK Ltd). Inter- and intra-assay coefficients of variation were $12.7 \%$ and $8.0 \%$, respectively. The limit of sensitivity of the assay (calculated as $2 \times$ SD above nonspecific binding) was $7.8 \mathrm{fmol}$ $\left[{ }^{3} \mathrm{H}\right]$ oxytocin bound $\mathrm{mg}^{-1}$ protein.

\section{Protein assay}

Protein was measured by the method of Lowry et al. (1951). Volumes of reagents were reduced so that the assay could be carried out in 96-well microtitre plates (No. 611 F96; Sterilin, Hounslow) which were read at $720 \mathrm{~nm}$ (Argus 400 Microplate Reader: Canberra Packard, Pangbourne).

\section{Radioimmunoassay for $P G F_{2 a}$}

Triplicate samples of medium $(25 \mu$ l) diluted 1:25 with assay buffer $\left(0.1 \mathrm{~mol}\right.$ Tricine $1^{-1}, \mathrm{pH} 8.0$, containing $154 \mathrm{mmol}$ sodium chloride $\mathrm{I}^{-1}, 0.1 \%$ sodium azide and $0.1 \%$ gelatine) were assayed with rabbit anti-PGF $2 a-B S A$ ( $100 \mu l$; PG002: Steranti Research Ltd, London Road, St Albans, Herts) and $\left[5,6,8,9,11,12,14,15(n)-{ }^{3} \mathrm{H}_{\mathrm{PGF}}(25 \mu \mathrm{l}\right.$ containing 8000 d.p.m.; 
$7.51 \mathrm{TBq}$ mmol; Amersham International plc, Aylesbury, Buckinghamshire). Assays were incubated for $20 \mathrm{~h}$ at $4^{\circ} \mathrm{C}$. Separation of free from antibody-bound labelled $\mathrm{PGF}_{2 \alpha}$ was achieved by addition of $1 \mathrm{ml} \mathrm{1 \%}$ activated charcoal (Sigma Chemical Company; previously sieved through $0.0053 \mathrm{~mm}$ mesh) in assay buffer containing $0.1 \%$ dextran (T-70; Pharmacia LKB, Uppsala), followed by centrifugation at $1000 \mathrm{~g}$ for $20 \mathrm{~min}$. Supernatants were decanted into polyethylene vials (Canberra Packard) containing scintillation fluid (5 ml Lumac Aqua Luma Plus, Rhone Poulenc Laboratory Products, Eccles, Manchester) and counted on a liquid scintillation analyser (Tricarb 1900 CA: Canberra Packard) fitted with a radioimmunoassay software package (Securia 2200). Sensitivity of the assay was $16.8 \mathrm{fmol}$ per tube and intra- and interassay coefficients of variation were $5.6 \%$ and $7.1 \%$, respectively.

\section{Effect of culture on endometrial and myometrial oxytocin receptor concentrations}

Caruncular endometrium and intercaruncular endometrium from 14 ewes (range 5-13 days after oestrus) and myometrium from four ewes (day 5, $n=2$; day 10, $n=1$; day 13, $n=1$ ) were cultured for up to $96 \mathrm{~h}$. Concentrations of oxytocin receptor were measured at the time of tissue collection and after 24 , 48,72 and $96 \mathrm{~h}$ in culture. In a second experiment, caruncular and intercaruncular endometrium from one ewe on each of days 9 and 10 after oestrus were cultured for a maximum of 10 days. Receptor measurements were made at the time of tissue collection and after 2, 4, 6, 8 and 10 days in culture.

Receptor affinity and maximal binding were measured in pooled membrane fractions prepared from caruncular endometrium ( $n=6$ dishes) and intercaruncular endometrium $(n=$ 6 dishes), collected from a ewe on day 9 of the cycle and cultured for $96 \mathrm{~h}$. Binding of $\left[{ }^{3} \mathrm{H}\right]$ oxytocin (seven concentrations ranging from 0.312 to $10.0 \mathrm{nmoll}^{-1}$ ) was analysed using the method of Scatchard (1949).

\section{Effect of different sources of protein in the culture medium on concentrations of receptor in endometrial explants}

Caruncular and intercaruncular endometrium from two ewes were cultured in triplicate dishes with (a) control medium (containing $5 \% \mathrm{v} / \mathrm{v}$ fetal calf serum); (b) medium containing charcoal-treated fetal calf serum $(5 \% \mathrm{v} / \mathrm{v})$ prepared by incubating serum with activated charcoal $(8 \% \mathrm{w} / \mathrm{v})$, at room temperature for $2 \mathrm{~h}$ followed by $4 \mathrm{~h}$ at $4^{\circ} \mathrm{C}$; the charcoal was then removed by centrifugation and filtration and the serum sterilized by filtration; (c) ovariectomized sheep serum $(5 \% \mathrm{v} / \mathrm{v})$; (d) ovariectomized sheep serum that had been charcoal-treated $(5 \% \mathrm{v} / \mathrm{v})$; and (e) BSA (0.1\% w/v; Sigma Chemical Company). Receptor concentrations were measured at the time of tissue collection and after $96 \mathrm{~h}$ of culture.

\section{Effect of fetal calf serum, phenol red and insulin on endometrial receptor concentrations}

Explants of caruncular and intercaruncular endometrium collected from three ewes were cultured in control medium, medium without fetal calf serum or medium without insulin. Because serum proteins and insulin are required to ensure long. term viability of tissue in vitro these cultures were terminated after $24 \mathrm{~h}$. Receptor measurements were made at the time of tissue collection and after $24 \mathrm{~h}$ in culture. Explants were cultured in medium without phenol red for up to $96 \mathrm{~h}$. Oxytocin receptors were measured at the time of tissue collection and after 24,48 , 72 and $96 \mathrm{~h}$ in culture.

\section{Effect of actinomycin $D$ and cycloheximide on receptor concentrations}

Explants of caruncular and intercaruncular endometrium from three ewes were cultured in medium containing actinomycin D (80 nmol 1 ${ }^{-1}$; Boehringer Mannheim, Germany) an RNA synthesis inhibitor or cycloheximide $\left(3.5 \mu \mathrm{mol} \mathrm{l}^{-1}\right.$; Sigma Chemical Company), a protein synthesis inhibitor. Receptor concentrations were measured at the time of tissue collection and after $96 \mathrm{~h}$ in culture.

\section{Co-culture experiment}

Explants of caruncular and intercaruncular endometrium collected from three ewes were cultured on two grids in each culture dish with either one empty grid or with explants of lung, kidney or corpus luteum on the third grid (about $50 \mathrm{mg}$ per grid). Receptor concentrations were measured at the time of tissue collection and after 48 or $96 \mathrm{~h}$ in culture.

\section{Effect of oxytocin on PGF ${ }_{2 a}$ production by endometrial explants}

Caruncular and intercaruncular endometrium from five ewes were used in experiments designed to investigate the ability of oxytocin to stimulate secretion of $\mathrm{PGF}_{2 \alpha}$ in freshly collected endometrium and cultured explants. Explants were cultured in $3.5 \mathrm{~cm}$ dishes (Falcon 1008) containing $4.5 \mathrm{ml}$ medium with one stainless steel grid $(23 \mathrm{~mm} \times 20 \mathrm{~mm} \times 4 \mathrm{~mm})$ per dish. Endometrium was prepared as for the other experiments and then the explants were blotted on sterile filter paper and $100 \mathrm{mg}$ tissue weighed onto each grid. Each measurement was made using triplicate dishes. Explants of endometrium from two ewes, both day 10 of the cycle, were challenged with oxytocin on the day of tissue collection: explants were incubated in control medium for $30 \mathrm{~min}$ at $37^{\circ} \mathrm{C}$; aliquots of medium $(2 \times 0.3 \mathrm{ml})$ were removed from each culture dish for $\mathrm{PGF}_{2 \alpha}$ estimation at a time designated as $0 \mathrm{~min}$ and immediately replaced with either the same volume of control medium or medium containing $2.25 \mathrm{nmol}$ oxytocin $\mathrm{I}^{-1}$ (Bachem UK Ltd, Saffron Walden, Essex), to give a final concentration of $0.5 \mu \mathrm{moll}^{-1}$. Aliquots of medium were collected after incubation for a further $60 \mathrm{~min}(t=\mathrm{Ih})$. Medium was immediately frozen on dry-ice and stored at $-80^{\circ} \mathrm{C}$ until required for assay of $\mathrm{PGF}_{2 \alpha}$. Endometrium collected from ewes on days 6,9 and 10 of the cycle was cultured for $48 \mathrm{~h}$ before exposure to oxytocin. Medium was changed after $24 \mathrm{~h}$ and again after a further $24 \mathrm{~h}$ when six dishes of each tissue from each of the three ewes received control medium and six dishes received medium containing the $\mathrm{PGF}_{2 \alpha}$ synthesis inhibitor indomethacin (11.2 $\mu \mathrm{mol} \mathrm{I}^{-1}$; Sigma Chemical Company). After a preincubation 


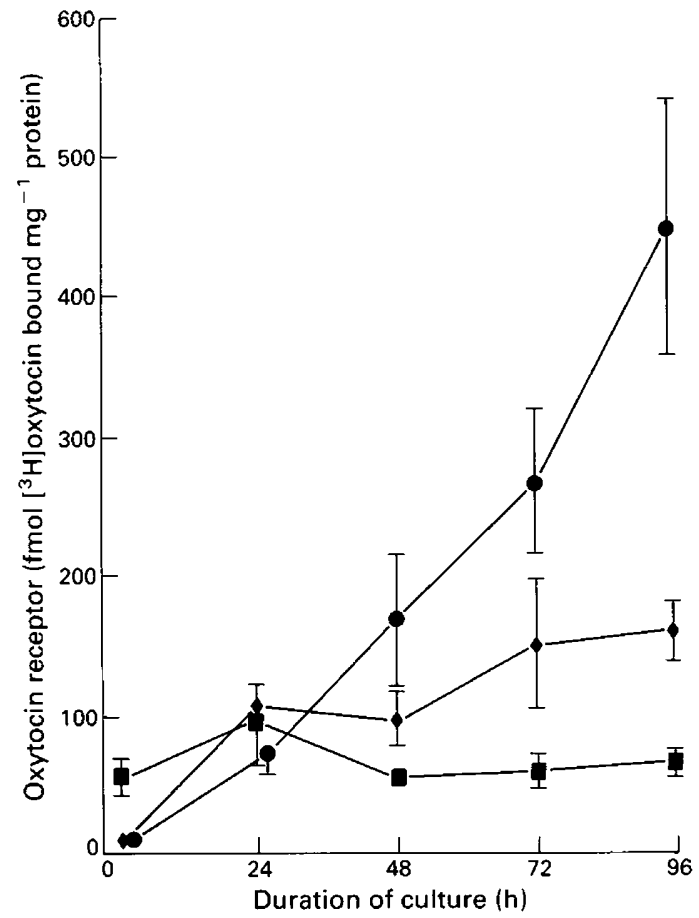

Fig. 1. Concentrations of oxytocin receptor in ovine caruncular endometrium $(\bullet)$, intercaruncular endometrium $(\boldsymbol{\bullet})$ and myometrium $(\boldsymbol{\square})$ at time of tissue collection and after $24,48,72$ or $96 \mathrm{~h}$ of culture (mean $\pm \mathrm{SEM}$ ).

period of $30 \mathrm{~min}$, aliquots of medium $(2 \times 0.3 \mathrm{ml})$ were removed for determination of $\mathrm{PGF}_{2 \alpha}$ concentration and replaced with either control medium, medium containing indomethacin, medium containing oxytocin or oxytocin and indomethacin so that the concentration of indomethacin was maintained during the experiment. Aliquots of medium were collected after a further $1 \mathrm{~h}$ and stored as described above.

The concentration of $\mathrm{PGF}_{2 \alpha}$ in a culture dish before addition of oxytocin or control medium at $0 \mathrm{~min}$ was subtracted from the concentration of $\mathrm{PGF}_{2 \alpha}$ present in the medium at $1 \mathrm{~h}$. Results are expressed as ng PGF $\mathrm{PG}_{2 \alpha}$ secreted per $100 \mathrm{mg}$ tissue $\mathrm{h}^{-1}$.

\section{Statistical analysis}

All values are reported as means \pm SEM where $n$ is the number of animals from which tissue was obtained. Statistical differences were determined by Student's $t$ test.

\section{Results}

Effect of culture on oxytocin receptor concentration in caruncular and intercaruncular endometrium and myometrium

The initial concentrations of oxytocin receptor were $10.4 \pm 1.8 \mathrm{fmol}\left[{ }^{3} \mathrm{H}\right]$ oxytocin bound $\mathrm{mg}^{-1}$ protein (range $1.1-21.9 ; n=14$ ewes) and $9.6 \pm 2.9 \mathrm{fmol}\left[{ }^{3} \mathrm{H}\right]$ oxytocin bound $\mathrm{mg}^{-1}$ protein (range $0.6-29.4 ; n=14$ ) in caruncular and intercaruncular endometrium, respectively (Fig. 1). The rate of increase in endometrial receptor concentration was similar at each stage of the oestrous cycle examined. Concentrations of oxytocin receptor in myometrium were $55.5 \pm 10.0 \mathrm{fmol}$ $\left[{ }^{3} \mathrm{H}\right]$ oxytocin bound $\mathrm{mg}^{-1}$ protein at the time of tissue collection (range 27.1-70.6; $n=4$ ) and remained unchanged throughout the $96 \mathrm{~h}$ culture. Mean values for receptor binding after $0,2,4,6,8$ and 10 days in culture were $8.5,28.9,58.4$, $67.5,72.3$ and $76.7 \mathrm{fmol}\left[{ }^{3} \mathrm{H}\right]$ oxytocin bound $\mathrm{mg}^{-1}$ protein for caruncular endometrium and 5.5, 69.7, 305.2, 411.9, 404.3 and $164.5 \mathrm{fmol} \mathrm{mg}^{-1}$ protein for intercaruncular endometrium. Scatchard plots of binding parameters were linear for caruncular and intercaruncular endometrium cultured for $96 \mathrm{~h}$. Apparent dissociation constants and maximal binding were 3.09 and $2.72 \mathrm{nmoll}^{-1}$ and 249 and $459 \mathrm{fmol} \mathrm{mg}^{-1}$ protein in caruncular and intercaruncular endometrium, respectively.

\section{Effects of different sources of serum protein on receptor binding activity}

In medium containing fetal calf serum, binding activity in caruncular and intercaruncular endometrium increased from mean concentrations of 16.6 and $18.8 \mathrm{fmol}\left[{ }^{3} \mathrm{H}\right]$ oxytocin bound $\mathrm{mg}^{-1}$ protein at the time of tissue collection to 106.2 and $333.3 \mathrm{fmol} \mathrm{mg^{-1 }}$ protein after $96 \mathrm{~h}$ in culture. When cultured in medium containing charcoal-treated fetal calf serum, ovariectomized sheep serum, charcoal-treated sheep serum and BSA, binding activities of explants from one ewe were not significantly different from the control at $96 \mathrm{~h}$. In the second ewe binding activities were similar to the control except in explants of intercaruncular endometrium cultured with ovariectomized sheep serum $\left(189.9 \pm 37.9 \mathrm{fmol} \mathrm{mg}^{-1}\right.$ protein) and in caruncular and intercaruncular endometrium cultured with BSA $\left(45.6 \pm 1.3\right.$ and $253.3 \pm 10.2 \mathrm{fmol} \mathrm{mg}^{-1}$ protein, respectively) where binding activities were significantly reduced $(P<0.05)$.

Effects of fetal calf serum, phenol red and insulin on concentrations of endometrial receptor binding activity

No inhibition of receptor production was evident after $24 \mathrm{~h}$ of culture in the absence of fetal calf serum or insulin (Table 1) and no significant differences were detected between oxytocin receptor concentrations in explants cultured in control medium and those cultured for up to $96 \mathrm{~h}$ in medium that did not contain phenol red (Table 2).

Effects of actinomycin $D$ and cycloheximide on receptor binding activity

Both actinomycin D and cycloheximide reduced receptor binding activity in caruncular and intercaruncular endometrium (Table 3). Viability of the explants cultured with cycloheximide or actinomycin was confirmed by the observation that basal secretion of $\mathrm{PGF}_{2 \alpha}$ by caruncular endometrium cultured with actinomycin or cycloheximide and intercaruncular endometrium cultured with actinomycin occurs at a rate similar to that in tissue cultured in control medium. Cycloheximide reduces $\mathrm{PGF}_{2 \alpha}$ secretion in intercaruncular endometrium in this culture system (data not shown). 
Table 1. Effect of fetal calf serum $(5 \% \mathrm{v} / \mathrm{v})$ and insulin $\left(10 \mu \mathrm{mol} \mathrm{l}^{-1}\right)$ on ovine oxytocin receptor binding activity (fmol $\left[{ }^{3} \mathrm{H}\right]$ oxytocin bound $\mathrm{mg}^{-1}$ protein) after $24 \mathrm{~h}$ in culture

\begin{tabular}{|c|c|c|c|c|}
\hline Endometrium & $\begin{array}{c}\text { + Fetal } \\
\text { calf serum }\end{array}$ & $\begin{array}{c}\text { - Fetal } \\
\text { calf serum }\end{array}$ & + Insulin & - Insulin \\
\hline Caruncular & $94.7 \pm 4.5$ & $103.3 \pm 10.1$ & $109.7 \pm 15.7$ & $92.7 \pm 10.0$ \\
\hline Intercaruncular & $52.4 \pm 3.1$ & $83.1 \pm 27.2$ & $53.3 \pm 6.1$ & $56.8 \pm 9.1$ \\
\hline
\end{tabular}

All values are means $\pm \operatorname{SEM}(n=3$ ewes).

Mean oxytocin receptor concentrations at time of tissue collection were $10.6 \pm 2.8 \mathrm{fmol}\left[{ }^{3} \mathrm{H}\right]$ oxytocin bound $\mathrm{mg}^{-1}$ protein in caruncular endometrium and $2.5 \pm 1.0 \mathrm{fmol} \mathrm{mg} \mathrm{m}^{-1}$ protein in intercaruncular endometrium.

Table 2. Effect of phenol red on ovine oxytocin receptor concentration (fmol $\left[{ }^{3} \mathrm{H}\right]$ oxytocin bound $\mathrm{mg}^{-1}$ protein) in explants of caruncular and intercaruncular endometrium cultured for $24,48,72$ or $96 \mathrm{~h}$

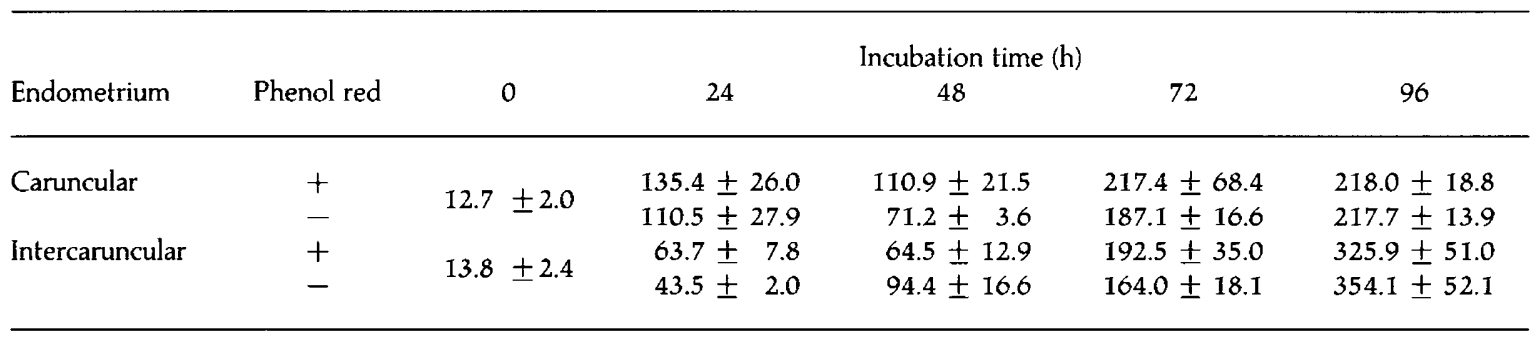

Values are means $\pm \operatorname{SEM}(n=3$ ewes).

Table 3. Oxytocin receptor binding activity ( $\mathrm{fmol}\left[{ }^{3} \mathrm{H}\right]$ oxytocin bound $\mathrm{mg}^{-1}$ protein) in ovine caruncular and intercaruncular endometrium cultured for $96 \mathrm{~h}$ with actinomycin or cycloheximide

\begin{tabular}{|c|c|c|}
\hline Treatment & $\begin{array}{l}\text { Caruncular } \\
\text { endometrium }\end{array}$ & $\begin{array}{l}\text { Intercaruncular } \\
\text { endometrium }\end{array}$ \\
\hline Control & $170.4 \pm 65.3$ & $565.9 \pm 172.6$ \\
\hline $\begin{array}{l}\text { Actinomycin D } \\
\left(80 \mathrm{nmol} 1^{-1}\right)\end{array}$ & $15.5 \pm 5.2$ & $25.6 \pm 4.9$ \\
\hline $\begin{array}{l}\text { Cycloheximide } \\
\left(3.5 \mu \mathrm{mol} \mathrm{l}^{-1}\right)\end{array}$ & $61.8 \pm 19.7$ & $29.6 \pm 10.6$ \\
\hline
\end{tabular}

All values are means $\pm \operatorname{SEM}(n=3$ ewes, triplicate cultures for each ewe). Oxytocin receptor binding activities at time of tissue collection in caruncular and intercaruncular endometrium were $3.0 \pm 1.5$ and $4.0 \pm 1.3 \mathrm{fmol}\left[{ }^{3} \mathrm{H}\right]$ oxytocin bound $\mathrm{mg}^{-1}$ protein, respectively.

\section{Co-culture experiment}

Co-culture with kidney and lung did not affect the concentration of receptor binding activity in explants of endometrium, but luteal tissue reduced binding activity in both intercaruncular and caruncular endometrium (Fig. 2). This effect was greater at $48 \mathrm{~h}$ than at $96 \mathrm{~h}$, possibly because the luteal tissue was becoming depleted of the inhibitor.

\section{Effect of oxytocin on $P G F_{2 a}$ production by fresh and cultured endometrium}

No detectable $\mathrm{PGF}_{2 \alpha}$ was produced in response to oxytocin by tissue challenged on the day of tissue collection (day 10 of the cycle). Effects of oxytocin on $\mathrm{PGF}_{2 \alpha}$ production by caruncular endometrium previously cultured for $48 \mathrm{~h}$ were variable with a significant response occurring only in tissue collected on day 10 of the cycle (Table 4). However, oxytocin significantly increased $\mathrm{PGF}_{2 \alpha}$ production by all cultured intercaruncular endometria. Indomethacin reduced mean $( \pm$ SEM) basal PGF $2 \alpha$ production by caruncular endometrium from $44.3 \pm 18.2$ to $9.1 \pm 7.9 \mathrm{ng}(100 \mathrm{mg})^{-1} \mathrm{~h}^{-1}$ and oxytocin-induced $\mathrm{PGF}_{2 \mathrm{a}}$ production from $79.5 \pm 35.9$ to $3.3 \pm 3.3 \mathrm{ng}(100 \mathrm{mg})^{-1} \mathrm{~h}^{-1}$. Basal production of $\mathrm{PGF}_{2 \alpha}$ in intercaruncular endometrium was reduced from $134.5 \pm 26.8$ to $66.5 \pm 39.6 \mathrm{ng}(100 \mathrm{mg})^{-1} \mathrm{~h}^{-1}$ by indomethacin and oxytocin-induced PGF $_{2 a}$ production was reduced from $401.7 \pm 74.7$ to $68.5 \pm 18.2 \mathrm{ng}(100 \mathrm{mg})^{-1} \mathrm{~h}^{-1}$. These data indicate that low concentrations of presynthesized $\mathrm{PGF}_{2 \alpha}$ are present in the tissues but de novo synthesis is required for oxytocin stimulated $\mathrm{PGF}_{2 a}$ secretion to occur.

\section{Discussion}

Concentrations of oxytocin receptor binding activity have previously been shown to increase in explants of ovine endometrium during culture (Sheldrick, 1990; Sheldrick, 1991). The experiments described here were designed to investigate the mechanism by which the apparent increase in receptor concentration occurs. Furthermore, we wished to establish whether the receptors synthesized are functional and, if so, what this tells us about control of oxytocin receptor synthesis in the cyclic ewe.

Oxytocin receptor binding increased in both caruncular and intercaruncular endometrium during culture with maximal binding being greater in intercaruncular than in caruncular 


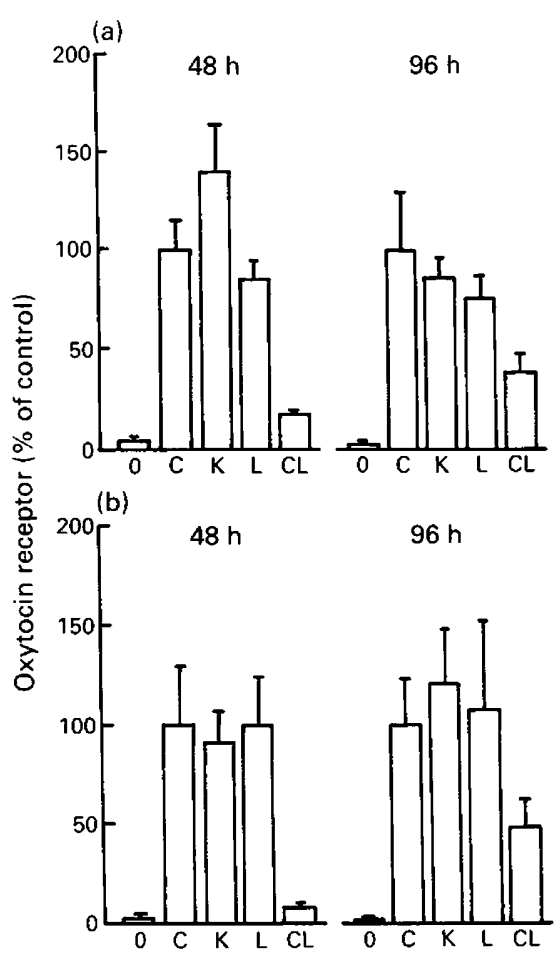

Fig. 2. Concentrations of oxytocin receptor in (a) ovine caruncular endometrium and (b) intercaruncular endometrium after culture for 48 or $96 \mathrm{~h}$ in control medium $(\mathrm{C})$ or with explants of kidney $(\mathrm{K})$, lung $(\mathrm{L})$ or corpus luteum (CL). Results are expressed as a percentage of the level of receptor in explants cultured in control medium at $48 \mathrm{~h}$ or at $96 \mathrm{~h}$. Concentrations of receptor in caruncular endometrium and intercaruncular endometrium at time of tissue collection $(0)$ were $3.4 \pm 1.5$ and $1.2 \pm 0.2 \mathrm{fmol}\left[{ }^{3} \mathrm{H}\right.$ loxytocin bound $\mathrm{mg}^{-1}$ protein, respectively. All values are means \pm SEM.

Table 4. Effect of oxytocin $\left(0.5 \mu \mathrm{moll}^{-1}\right)$ on $\mathrm{PGF}_{2 \alpha}$ secretion (ng $(100 \mathrm{mg})^{-1} \mathrm{~h}^{-1}$ ) by ovine endometrium previously cultured for $48 \mathrm{~h}$. Values represent the total amount of $\mathrm{PGF}_{2 \alpha}$ secreted during $\mathrm{Ih}$ following addition of either control medium or medium containing oxytocin

\begin{tabular}{llll}
\hline $\begin{array}{l}\text { Number } \\
\text { of ewes }\end{array}$ & $\begin{array}{c}\text { Day of } \\
\text { tissue } \\
\text { collection }\end{array}$ & Control & Oxytocin \\
\hline
\end{tabular}

Caruncular

endometrium

$\begin{array}{lrrc}3 & 6 & 30.4 \pm 2.7 & 33.9 \pm 5.3 \\ 15 & 9 & 80.5 \pm 26.2 & 146.9 \pm 29.2 \\ 14 & 10 & 22.1 \pm 13.0 & 163.1 \pm 31.9^{* *} \\ \text { ercaruncular } & & & \\ \text { endometrium } & & & \\ 3 & 6 & 91.6 \pm 57.4 & 286.0 \pm 25.1^{*} \\ 15 & 9 & 128.1 \pm 39.7 & 541.5 \pm 5.0^{* *} \\ 14 & 10 & 183.7 \pm 15.8 & 377.7 \pm 44.4^{* *}\end{array}$

All values are means \pm SEM for three replicate dishes.

${ }^{*} p<0.05 ;{ }^{* *} P<0.005$. endometrium. Apparent dissociation constants in cultured caruncular and intercaruncular endometrium were similar to those previously reported in cyclic ewes $\left(1.96 \mathrm{nmol} \mathrm{I}^{-1}\right.$ and $1.87 \mathrm{nmol}$ $1^{-1}$, respectively; Sheldrick and Flint, 1985). The rate of increase in receptor binding activity was similar irrespective of the day of the cycle on which culture was started, indicating that the rise in binding did not result from a predetermined event programmed to occur at the onset of luteolysis. Levels of binding in myometrium were higher than those in endometrium at the time of tissue collection and remained unchanged throughout $96 \mathrm{~h}$ of culture. The reason for the different responses by the three tissues studied here is not known but may indicate either that they respond differently to the culture conditions or that there are different populations of oxytocin receptor in the ovine uterus.

The increase in receptor binding did not appear to be the result of stimulation by hormonal factors in the medium. Oestrogen has been cited as a stimulator of oxytocin receptor synthesis in vivo and in vitro (Roberts et al., 1976; Soloff et al., 1983; McCracken et al., 1984; Matthews et al., 1991), but oestradiol has previously been shown to have no stimulatory effect on oxytocin receptor synthesis by ovine endometrium in vitro, and at a high concentration inhibited receptor synthesis (Sheldrick, 1990; Sheldrick and Flick-Smith, 1993). This hypothesis is supported by the experiments reported here where factors with possible oestrogenic activity were omitted from the medium without effect on oxytocin receptor binding activity. For example, phenol red has been shown to have oestrogenic activity in rat anterior pituitary cells (Hubert et al., 1986), MCF-7 human breast carcinoma cells (Berthois et al., 1986) and, to some extent, immature rat uterine cells (Welshons et al., 1988), but in the experiments reported here there was no effect of phenol red on oxytocin receptor binding activity. Fetal calf serum is also a possible source of oestrogen. However, explants cultured for $96 \mathrm{~h}$ with calf serum that had been treated with charcoal to remove steroid hormones (Jones et al., 1986) had receptor binding activity similar to that of explants cultured with untreated calf serum.

Receptor binding activity was generally unrelated to the nature of protein added to the culture medium. Substituting fetal calf serum with serum from ovariectomized sheep or ovariectomized sheep serum treated with charcoal did not inhibit the rise in receptor binding although the binding activity achieved in intercaruncular endometrium of one ewe cultured for $96 \mathrm{~h}$ with whole sheep serum was reduced, compared with the activity in tissue from the same ewe cultured with calf serum. Substituting BSA for fetal calf serum resulted in a rise in receptor binding activity, but binding at $96 \mathrm{~h}$ in endometrium from one ewe was significantly lower than in tissue cultured in the presence of calf serum. This result may reflect the requirement of both serum albumin and globulins for maintenance of mammalian cells in culture (Tozer and Pirt 1964). However, removing the source of serum protein for a shorter incubation $(24 \mathrm{~h})$ did not inhibit the rate of increase of receptor binding activity and therefore serum proteins in the medium must be excluded as a stimulus of receptor binding activity. The concentration of insulin in Trowell T8 $\left(10 \mu \mathrm{mol}^{-1}\right)$ is considerably higher than in most other culture media but omitting insulin from the medium did not affect the increase in oxytocin receptor binding activity in both cultured tissues. We conclude from these data that the rise in receptor 
binding activity during culture does not result from stimulation by constituents in the medium.

Addition of actinomycin to the medium reduced oxytocin receptor binding, indicating that the increase in binding activity during culture requires RNA synthesis and therefore results from de novo synthesis of either the receptor itself or of a protein required for processing or activating the receptor. Inhibition of the rise in binding by cycloheximide confirms that binding increases as a result of protein synthesis. Cycloheximide was more effective in reducing oxytocin binding activity in intercaruncular than in caruncular endometrium, which implies that the increase in receptor binding seen in these two tissues may occur in different ways, with de novo synthesis accounting for all increased binding in intercaruncular endometrium and a combination of de novo synthesis and receptor activation occurring in caruncular endometrium. Receptor activation could result from dissociation of ligand from receptor during culture giving an apparent rise in binding; however, this is unlikely as the method used to prepare tissues for receptor assay causes dissociation of oxytocinreceptor complexes and as a result total receptor is measured in the assay (Sheldrick and Flint, 1985). The action of actinomycin $\mathrm{D}$ in inhibiting oxytocin receptor synthesis is consistent with the data of French and Casida (1973) who found that intrauterine administration of actinomycin $\mathrm{D}$ blocked both naturally occurring and oestradiol-induced luteal regression in cyclic ewes.

To investigate whether the increase in receptor binding activity represented synthesis of functional oxytocin receptors, explants were challenged with oxytocin on the day of tissue collection and after $48 \mathrm{~h}$ in culture. The effect of oxytocin on $\mathrm{PGF}_{2 \alpha}$ secretion during the luteal phase of the ovine oestrous cycle is attenuated in vivo (McCracken, 1980) and in vitro (Roberts et al., 1976) and in the experiments described here no detectable $\mathrm{PGF}_{20}$ was produced in response to oxytocin by endometrium collected in mid-cycle, when receptor concentrations were at basal values. However, after $48 \mathrm{~h}$ in culture, oxytocin stimulated $\mathrm{PGF}_{2 a}$ production in all three samples of intercaruncular endometrium and in two of three samples of caruncular endometrium. The response of caruncular endometrium to oxytocin may be related to the day of the cycle on which the tissue was collected. In general, the degree of stimulation of $\mathrm{PGF}_{2 \alpha}$ production by oxytocin was greater in intercaruncular than in caruncular endometrium and this is consistent with the higher production of receptor in this tissue during culture. The fact that cultured endometrium responds to oxytocin by producing $\mathrm{PGF}_{2 \alpha}$ confirms that increased receptor binding results from synthesis of functional oxytocin receptors. Inhibition of oxytocin-induced $\mathrm{PGF}_{2 \alpha}$ production by indomethacin has been reported to occur in endometrium from ovariectomized ewes in which oxytocin receptors had been coupled to PGF $_{2 \alpha}$ secretory pathway by steroid hormones administered in vivo (Raw and Silvia, 1991).

The results presented here have implications for the control of oxytocin receptor synthesis during the oestrous cycle. During the luteal phase of the oestrous cycle when the corpus luteum secretes oxytocin and progesterone at maximal rates, endometrial oxytocin receptor concentrations are low and both hormones have been shown to affect concentrations of uterine oxytocin receptor (Flint and Sheldrick, 1985; Leavitt et al., 1985; Vallet and Lamming, 1991; Sheldrick, 1992; Zhang et al., 1992).
It can be assumed that progesterone and oxytocin were affecting oxytocin receptor synthesis at the time that the tissues were collected for use in the experiments described here. Co-culture of endometrium with explants of corpora lutea inhibited receptor synthesis in vitro and this result indicates that secretory products of the corpus luteum act directly on the endometrium to control receptor production. This finding is supported by the evidence that uterine explants obtained from ovariectomized ewes, and, therefore, not exposed to inhibitors of ovarian origin in vivo, had higher basal receptor binding activity than that seen in ewes in the mid-luteal phase of the cycle and this high level of activity remained unchanged during $96 \mathrm{~h}$ in culture (Sheldrick and Flick-Smith, 1993). Although progesterone or oxytocin are obvious candidates for this inhibitory role, other luteal products cannot be discounted, as recent studies on the effect of $\alpha$ interferon on endometrial oxytocin receptor binding in culture suggest that any agent affecting protein kinase $\mathrm{C}$ activity may influence concentrations of oxytocin receptor (Abayasekara et al., 1992).

\section{References}

Abayasekara DRE, Sheldrick EL, Flick-Smith HC, Commander H and Flint APF (1992) Protein kinase $C$ in the sheep endometrium: mechanism by which interferon inhibits oxytocin receptor expression Journal of Reproduction and Fertility Abstract Series 9 Abstract 65

Berthois Y, Katzenellenbogen JA and Katzenellenbogen BS (1986) Phenol red in tissue culture media is a weak estrogen: Implications concerning the study of estrogen-responsive cells in culture Proceedings of the National Academy of Sciences USA 83 2496-2500

Clements JA and Funder JW (1986) Arginine vasopressin (AVP) and AVP-like immunoreactivity in peripheral tissues Endocrine Reviews 7 449-460

Flint APF and Sheldrick EL (1983) Evidence for a systemic role for ovarian oxytocin in luteal regression in sheep Journal of Reproduction and Fertility 67 $215-225$

Flint APF and Sheldrick EL (1985) Continuous infusion of oxytocin prevents induction of uterine oxytocin receptor and blocks luteal regression in cyclic ewes Journal of Reproduction and Fertility 75 623-631

Flint APF, Sheldrick EL, McCann T\} and Jones DSC (1990) Luteal oxytocin: characteristics and control of synchronous episodes of oxytocin and $\mathrm{PGF}_{2 a}$ secretion at luteolysis in ruminants Domestic Animal Endocrinology 7 111-124

French LR and Casida LE (1973) Effect of actinomycin D on corpus luteum regression in ewes Journal of Animal Science 37 1218-1221

Hubert J-F, Vincent A and Labrie F (1986) Estrogenic activity of phenol red in rat anterior pituitary cells in culture Biochemical and Biophysical Research Communications 141 885-891

Jones A, Ratcliffe JG and Swift AD (1986) A comparison of physical methods of obtaining analyte-free serum suitable for use in radioimmunoassay of thyroxine and triiodothyronine Communications in Laboratory Medicine 2 $128-130$

Leavitt WW, Okulicz WC, McCracken JA, Schramm W and Robidoux WF (1985) Rapid recovery of nuclear estrogen receptor and oxytocin receptor in the ovine uterus following progesterone withdrawal Journal of Steroid Biochemistry 22 $687-691$

Lowry OH, Rosebrough NJ, Farr AL and Randall RJ (1951) Protein measurement with the Folin phenol reagent Journal of Biological Chemistry 193 265-275

McCracken JA (1980) Hormone receptor control of prostaglandin $F_{2 a}$ secretion by the ovine uterus Advances in Prostaglandin and Thromboxane Research 8 1329-1344

McCracken JA, Schramm W and Okulicz WC (1984) Hormone receptor control of pulsatile secretion of $\mathrm{PGF}_{20}$ from the ovine uterus during luteolysis and its abrogation in early pregnancy Animal Reproduction Science 7 31-55

Matthews EL, Ayad VJ and Wathes DC (1991) The effect of oestradiol-17 $\beta$ on oxytocin receptor concentrations in the reproductive tract of the anoestrous ewe Journal of Reproduction and Fertility Abstract Series $\mathbf{8}$ Abstract 81 
Raw RE and Silvia WJ (1991) Activity of phospholipase C and release of prostaglandin $F_{2 \alpha}$ by endometrial tissue from ovariectomized ewes receiving progesterone and estradiol Biology of Reproduction 44 404-412

Roberts JS, McCracken JA, Gavagan JE and Soloff MS (1976) Oxytocin-stimulated release of prostaglandin $\mathrm{F}_{20}$ from ovine endometrium in vitro: correlation with estrous cycle and oxytocin-receptor binding Endocrinology 99 1107-1114

Scatchard G (1949) The attraction of proteins for small molecules and ions Annals of the New York Academy of Sciences $51660-672$

Sheldrick EL (1990) Effect of oestradiol-17B on uterine oxytocin receptor synthesis in vivo and in vitro Journal of Reproduction and Fertility Abstract Series 5 Abstract 15

Sheldrick EL (1991) Oxytocin and luteal maintenance in the ewe Joumal of Reproduction and Fertility Supplement 43 105-107

Sheldrick EL (1992) Effect of continuous infusion of oxytocin on ovarian function and uterine oxytocin receptor concentrations in the cyclic ewe Reproduction Fertility and Development 4 505-513

Sheldrick EL and Flick-Smith HC (1993) Effect of ovarian hormones on oxytocin receptor concentrations in explants of uterus from ovariectomized ewes Joumal of Reproduction and Fertility $97241-245$

Sheldrick EL and Flint APF (1985) Endocrine control of uterine oxytocin receptors in the ewe Journal of Endocrinology $106249-258$

Sheldrick EL and Flint APF (1990) Effect of continuous infusion of oxytocin on prostaglandin $\mathrm{F}_{2 a}$ secretion and luteolysis in the cyclic ewe Reproduction Fertility and Development 2 89-99
Silvia WJ, Lewis GS, McCracken JA, Thatcher WW and Wilson, Jr (1991) Hormonal regulation of uterine secretion of prostaglandin $F_{2 \alpha}$ during luteolysis in ruminants Biology of Reproduction 45 655-663

Soloff MS, Fernstrom MA, Periyasamy S, Soloff S, Baldwin S and Weider M (1983) Regulation of oxytocin receptor concentration in rat uterine explants by estrogen and progesterone Canadian Journal of Biochemistry and Cell Biology $61625-630$

Tozer BT and Pirt SJ (1964) Suspension culture of mammalian cells and macromolecular growth-promoting fractions of calf serum Nature 201 375-378

Trowell OA (1959) The culture of mature organs in a synthetic medium Experimental Cell Research 16 118-147

Vallet JL and Lamming GE (1991) Ovine conceptus secretory proteins and bovine recombinant interferon $\alpha_{1}-1$ decrease endometrial oxytocin receptor concentrations in cyclic and progesterone-treated ovariectomized ewes Joumal of Endocrinology 131 475-482

Vallet JL, Lamming GE and Batten M (1990) Control of endometrial oxytocin receptor and uterine response to oxytocin by progesterone and oestradiol in the ewe Joumal of Reproduction and Fertility $90625-634$

Welshons WV, Wolf MF, Murphy CS and Jordan VC (1988) Estrogenic activity of phenol red Molecular and Cellular Endocrinology 57 169-178

Zhang J, Weston PG and Hixon JE (1992) Role of progesterone and oestradiol in the regulation of uterine oxytocin receptors in ewes Joumal of Reproduction and Fertility 94 395-404 